\title{
Bilateral vulval filarial elephantiasis
}

\author{
Mandira Chakraborty, ${ }_{1}^{1}$ Hasina Banu, ${ }^{2}$ Partha Pratim Chakraborty ${ }^{3}$
}

'Department of Microbiology, Medical College, Kolkata, India ${ }^{2}$ Department of Microbiology, R G Kar Medical College and Hospital, Kolkata, India ${ }^{3}$ Dpartment of Medicine Midnapore Medical College and Hospital, Midnapore, India

\section{Correspondence to}

Dr Partha Pratim Chakraborty, docparthapc@yahoo.co.in

Accepted 6 February 2018

Check for updates

To cite: Chakraborty M, Banu H, Chakraborty PP. BMJ Case Rep Published Online First: [please include Day Month Year]. doi:10.1136/ bcr-2018-224250

\section{DESCRIPTION}

A 25-year-old unmarried woman, resident of a filarial endemic region, presented with progressive swelling of the vulva along with recent onset redness, dragging pain and consequent difficulty in walking. She had noticed the vulval swelling about 2 years before her presentation and had been suffering from recurrent episodes of low-grade fever for the preceding 2 years. The swelling had been reducible initially and became non-reducible after about 6 months. She denied any pelvic surgery, radiation or trauma. Her medical and family histories were unremarkable. A thorough systemic examination did not document any abnormality. Genital examination revealed non-ulcerative bilateral vulval swelling with bosselated surface, hard in consistency with raised local temperature and palpable bilateral superficial inguinal lymph nodes (figure 1). Baseline work-up was as follows: haemoglobin $11 \mathrm{~g} / \mathrm{dL}$, total leucocytes count 7000 cells $/ \mathrm{mm}^{3}$, neutrophil $60 \%$, lymphocytes $20 \%$, eosinophil $12 \%$ and erythrocyte sedimentation rate (ESR) $60 \mathrm{~mm}$ in first hour. Peripheral blood collected at midnight examined by concentration technique using Leishman stain was negative for microfilaria. However, immunochromatographic test for microfilarial antigen was positive. Mantoux test was negative, chest X-ray was normal and pelvic ultrasonography was unremarkable. Both fine needle aspiration cytology and punch biopsy from the involved area showed features of chronic inflammation as evidenced by perivascular collection of lymphocytes, plasma cells, and eosinophils and occasional foreign body granuloma without acid fast bacilli in Ziehl-Neelsen stain, fungal hyphae in Periodic acid-Schiff stain or Donovan bodies or Chlamydia elementary bodies in Giemsa stain. The woman was treated with diethylcarbamazine (DEC) in three divided doses of $6 \mathrm{mg} /$ $\mathrm{kg} /$ day for 21 days and was advised to wear tight undergarments and to maintain local hygiene to prevent any secondary infection. Cosmetic surgery was advised after completion of the course of DEC, and the woman was referred to the department of plastic surgery.

Lymphedema is swelling of soft tissue that develops following accumulation of protein-rich interstitial fluid secondary to improper lymphatic drainage of the involved area. If untreated for prolonged period, lymphatic obstruction can ultimately result in massive lymphedema, also known as elephantiasis, and vulval elephantiasis accounts for only about $1 \%-2 \%$ of total elephantiasis cases. Infections like filariasis, tuberculosis, lymphogranuloma venereum, donovanosis and a number of non-infective conditions such as genital malignancies, metastatic Crohn's disease, inguinal and pelvic lymph node dissection, genital

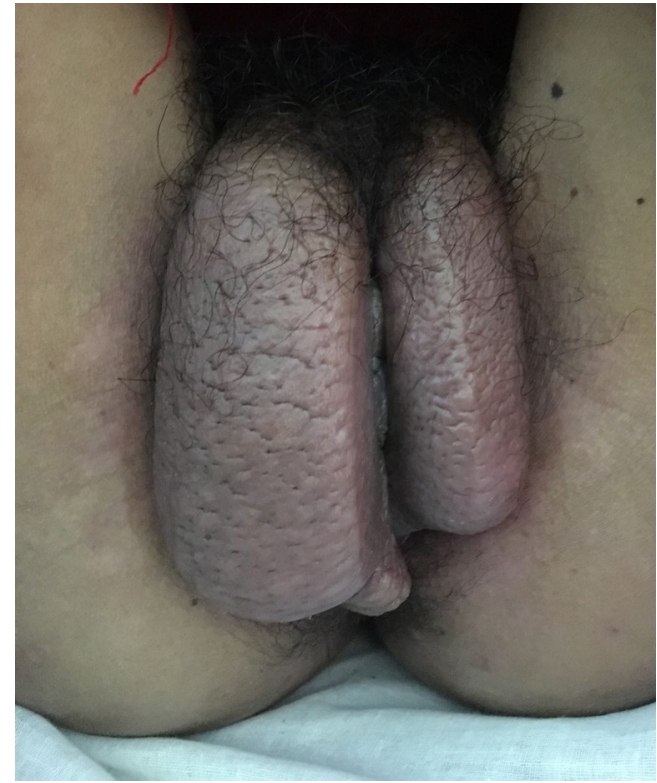

Figure 1 Bilateral vulval swelling.

radiation, vulvectomy or pelvic trauma can at times give rise to genital elephantiasis. ${ }^{1}$ Genital elephantiasis, also known as esthiomene, is rare; even rarer is genital elephantiasis secondary to filarial infections, seen in only $1 \%-2 \%$ of all such cases. ${ }^{2}$ Lymphatic filariasis is caused by Wuchereria bancrofti and Brugia malai. The third-stage microfilarias after entering the human body by bite of a mosquito reside within the lymphatic system and begin to grow into adult forms. After acquiring sexual maturity, the male fertilises the female to give birth to the larva. The lymphatic damage is caused by the movement of the adult worm producing inflammatory reactions and resultant lymphangitis, leading to stasis of lymph and subsequent lymphedema. To overcome the stasis, affected lymphatics undergo dilatation, become tortuous and a number of collateral lymph vessels develop. Further movement of adult worm ultimately leads to hypertrophy and hyperplasia of lymphatic endothelium which further aggravates stasis. Thus with time the lymphatic obstruction becomes irreversible and leads to elephantiasis. It is postulated that as long as the adult worms are alive, the lymphatic vessels remain patent. Death of the worm, however, leads to extensive perilymphangitis, progressive fibrosis and obliteration of vessels. ${ }^{3}$ Therefore, the worm is usually not found in peripheral blood or within the involved tissue in these patients and clinical suspicion along with ancillary tests are the cornerstones of diagnosis. 


\section{Learning points}

- Though vulval elephantiasis due to filarial infection is very rare, in endemic countries it should be considered as one of the important causes of elephantiasis, both limb and genital.

- Vulval filariasis is essentially a clinical diagnosis. In the absence of documentation of filarial worm in peripheral smear or within the involved tissue section, elevated absolute eosinophil count, positive filarial antigen assay and ruling out other possible differentials establish the diagnosis.

- Genital elephantiasis significantly affects the physical, mental and social well-being of a patient; so early diagnosis and effective treatment of filariasis is the only key to avoid such physical disability and extreme mental anguish.

- Aims of the management of vulval filariasis are reduction of vulval swelling, prevention of secondary infections and restoration of the normal genital appearance and sexual functions. Diethylcarbamazine with or without antibiotics and cosmetic surgery are the available therapeutic options.
In addition to DEC that kills both the adult worms and microfilaria, maintenance of local hygiene, proper skin care and prompt treatment of secondary bacterial infections, if any, are of utmost importance. However, majority require cosmetic surgical interventions like excision therapy with or without split thickness skin graft or thigh flaps. Though uncommon, recurrence after initial reconstructive surgery may also be encountered.

Contributors All authors were involved in diagnosis and management of the patient. MC and HB did the literature search. PPC wrote the manuscript.

Competing interests None declared.

Patient consent Obtained.

Provenance and peer review Not commissioned; externally peer reviewed.

(c) BMJ Publishing Group Ltd (unless otherwise stated in the text of the article) 2018. All rights reserved. No commercial use is permitted unless otherwise expressly granted.

\section{REFERENCES}

1 Mohan H, Bisht B, Goel P, et al. Vulval elephantiasis: a case report. Case Rep Infect Dis 2012:2012:1-3.

2 Chintamani SJ, Singh J, Tandon M, et al. Vulval elephantiasis as a result of tubercular lymphadenitis: two case reports and a review of the literature. J Med Case Rep 2010;4:369

3 Dreyer G, Norões J, Figueredo-Silva J, et al. Pathogenesis of lymphatic disease in bancroftian filariasis: a clinical perspective. Parasitol Today 2000;16:544-8.

Copyright 2018 BMJ Publishing Group. All rights reserved. For permission to reuse any of this content visit

http://group.bmj.com/group/rights-licensing/permissions.

BMJ Case Report Fellows may re-use this article for personal use and teaching without any further permission.

Become a Fellow of BMJ Case Reports today and you can:

- Submit as many cases as you like

- Enjoy fast sympathetic peer review and rapid publication of accepted articles

- Access all the published articles

- Re-use any of the published material for personal use and teaching without further permission

For information on Institutional Fellowships contact consortiasales@bmjgroup.com

Visit casereports.bmj.com for more articles like this and to become a Fellow 